\title{
A Study of the Uptake of Heavy Metals by Plants near Metal-Scrap Dumpsite in Zaria, Nigeria
}

\author{
Zakka Israila Yashim, ${ }^{1}$ Omoniyi Kehinde Israel, ${ }^{1}$ and Musa Hannatu ${ }^{2}$ \\ ${ }^{1}$ Department of Chemistry, Ahmadu Bello University, PMB 1045, Samaru, Zaria, Nigeria \\ ${ }^{2}$ Department of Biological Sciences, Ahmadu Bello University, PMB 1045, Samaru, Zaria, Nigeria \\ Correspondence should be addressed to Zakka Israila Yashim; ziyashim@abu.edu.ng
}

Received 22 May 2014; Accepted 18 July 2014; Published 12 August 2014

Academic Editor: Luqman Chuah Abdullah

Copyright (c) 2014 Zakka Israila Yashim et al. This is an open access article distributed under the Creative Commons Attribution License, which permits unrestricted use, distribution, and reproduction in any medium, provided the original work is properly cited.

\begin{abstract}
The research work investigates the metal uptake of the plants Lycopersicon esculentum (tomato), Rumex acetosa (sorrel), and Solanum melongena (garden egg) collected from experimental sites and a control area in Zaria, Nigeria. The concentrations of Cd, $\mathrm{Cu}, \mathrm{Fe}, \mathrm{Pb}, \mathrm{Mn}$, and $\mathrm{Zn}$ in different parts of each of the plant species grown on the experimental and control soils were determined using atomic absorption spectrophotometry. The experimental levels of the metals were higher than those at the control site and the limits recommended by Food and Agricultural Organisation/World Health Organisation (FAO/WHO). Solanum melongena showed bioaccumulation factor $(\mathrm{BF})$ and transfer factor $(\mathrm{TF})$ greater than 1 for $\mathrm{Cd}, \mathrm{Pb}$, and $\mathrm{Mn}$; Rumex acetosa showed $\mathrm{BF}$ and $\mathrm{TF}$ greater than 1 for $\mathrm{Mn}$ and $\mathrm{Zn}$, and $\mathrm{TF}$ was greater than 1 for $\mathrm{Cu}$ and Fe; Lycopersicon esculentum had only the $\mathrm{TF}$ for $\mathrm{Fe}, \mathrm{Pb}$, $\mathrm{Mn}$, and $\mathrm{Zn}$ greater than 1 . This results implies that Solanum melongena and Rumex acetosa plants can be effectively used for phytoremediation of $\mathrm{Cd}, \mathrm{Pb}, \mathrm{Mn}$, and $\mathrm{Zn}$ from the dumpsite. Pearson's correlation coefficient values $(r)$ were greater than 0.75 for all the metals studied which indicated that the high metal level in the experimental soil was a result of the metal-scrap.
\end{abstract}

\section{Introduction}

Heavy metals constitute a group of metals and metalloids with atomic density greater than $4 \mathrm{~g} / \mathrm{cm}^{3}$ or 5 times or more greater than water [1]. The toxicity of heavy metals is a problem of increasing significance for ecological, nutritional, and environmental reasons.

It is evident that, among others, manufacturing activities involving the disposal of metal containing materials into the biosphere may soon trigger a silent epidemic of environmental metal poisoning [2]. Toxic metals cannot be biodegraded. They have long half-life in the environment and biological system; hence, they pose an environmental problem $[3,4]$.

Despite the best attempts at waste avoidance, reduction, reuse, and recovery, landfill and disposal of metal still constitute a principal focus by environmental scientist. It has been observed that the larger the urban area, the lower the quality of the environment. So solid waste disposal and management have reached a critical stage in major towns and cities of Nigeria [5].

Environmental restoration of metal-polluted soils using a plant-based technology has attracted increasing interest in the last two decades. Phytoremediation has been developed as a cost effective and environmentally friendly remediation method of contaminated soils. It is an economically attractive approach to decontaminate soils polluted by heavy metals. Because of its relatively low costs, phytoremediation poses a viable approach to cleaning up soils [6-10]. The use of plants to extract and translocate metals to their harvestable parts (phytoextraction) is aimed at reducing the concentration of metals in contaminated soils to regulatory levels within a reasonable time frame [11]. Some plant species have developed tolerance towards metals and others (hyperaccumulators) are characterised by their ability to accumulate high quantities of metals in their tissues [12]. Hyperaccumulators are plants that achieve a plant-to-soil metal-concentration ratio (bioaccumulation factor) and shoot-to-root metal-concentration ratio 
(transfer factor) greater than one. The accumulation of these metals may vary from plant to plant and soil to soil. The metal availability to plants depends on total concentration of metals in the soil and the forms in which they occur, $\mathrm{pH}$, organic carbon, cation-exchange capacity, stage of growth of plants, and microorganisms around the root zone $[13,14]$. If these factors are constant, the uptake of a metal by different plant species may be compared.

Gaskiya metal dumpsite occupies an estimated capacity of $20 \mathrm{~m} \times 6 \mathrm{~m}$, and several crops such as Lycopersicon esculentum (tomatoes), Rumex acetosa (sorrel), and Solanum melongena (garden egg) are grown on the soil near the dumpsite.

The dumping of metal scraps at Gaskiya in Zaria, Nigeria $\left(11^{\circ} 07^{\prime} 51^{\prime \prime} \mathrm{N} ; 7^{\circ} 43^{\prime} 43^{\prime \prime} \mathrm{E}\right)$, implies that there might be more or less pollution of the soil.

The aim of this study is to compare the uptake of some metals by Lycopersicon esculentum (tomatoes), Rumex acetosa (sorrel), and Solanum melongena (garden egg) grown on the soil near a metal-scrap dumpsite in order to determine the bioaccumulation factor (BF) and transfer factor (TF), hence, the plants phytoremediation potentials.

\section{Materials and Methods}

2.1. Sample Collection. Whole plant sample of Lycopersicon esculentum (tomato), Rumex acetosa (sorrel), and Solanum melongena (garden egg) was collected $50 \mathrm{~m}$ from Gaskiya metal-scrap dumpsite, while soil samples ( $150 \mathrm{~g}$ ) were collected from the surface to a depth of $15 \mathrm{~cm}$ around each plant root zone, using hand trowel, and then mixed together. Background soil (150 g) and plant samples were also obtained as control from a farmland that is at a distance of $5 \mathrm{~km}$ away from the dumpsite. The collection was done by dividing the experimental and control sites each into four quadrants; five plant samples or soil samples were collected from each quadrant in a diagonal basis following the methods of Nuonom et al. [15].

2.2. Sample Treatment. The collected soil samples were airdried at room temperature for 3 days, while the shoots and roots of the plants were washed, separated, and air-dried. The soils were ground and sieved (500 $\mu \mathrm{m}$ sieve), dried in an oven at $65 \pm 1^{\circ} \mathrm{C}$ for $16 \mathrm{hrs}$ and then kept in clean polythene bags for further analysis.

One gramme of each of the soil and plant samples was digested separately with $10 \mathrm{~cm}^{3}$ of aqua regia (a mixture of 3 parts concentrated $\mathrm{HCl}$ to 1 part concentrated $\mathrm{HNO}_{3}$ ) on a hot plate in a fume cupboard, until a clear solution was obtained. Distilled water was added periodically to avoid drying up of the digest. To the hot solution, $30 \mathrm{~cm}^{3}$ of distilled water was then added and filtered through a Whatman number 41 filter paper into a $50 \mathrm{~cm}^{3}$ standard volumetric flask and the solution made up to the mark with distilled water [16].

Cadmium, copper, iron, lead, manganese, and zinc were analysed in the plant and soil samples using a UNICAM 969 atomic absorption spectrometer [16], with the analyses being done in triplicate.
Pearson' correlation coefficient $(r)$ was calculated between metal levels in soil and plant samples for individual metals using the following formula:

$$
r=\frac{n \sum x y-\sum x \sum y}{\sqrt{ }\left[n \sum x^{2}-\left(\sum x\right)^{2}\right]\left[n \sum y^{2}-\left(\sum y\right)^{2}\right]},
$$

where $x$ and $y$ were the two variables, plant samples and soil sample, respectively, while $\mathrm{n}$ is for the pairs of observed values of the these variables [16].

The bioaccumulation factor (BF) and the transfer factor (TF) were calculated to determine the degree of metal accumulation in the plants grown at the farm site close to the metal-scrap dumpsite [17]. Consider

$$
\begin{gathered}
\mathrm{BF}=\frac{\text { Concentration of metal in plant }}{\text { Concentration of metal in soil }} \\
\mathrm{TF}=\frac{\text { Concentration of metal in plant shoot }}{\text { Concentration of metal in plant root }} .
\end{gathered}
$$

\section{Results and Discussion}

3.1. Metal Contents in Different Parts of the Plants. In Solanum melongena plant (Figure 1(a)), there was generally an increase in the level of the metals in the shoot compared to the root (except $\mathrm{Zn}$ ). The total metals in the soil follow the ranking $\mathrm{Fe}>\mathrm{Zn}>\mathrm{Pb}>\mathrm{Mn}>\mathrm{Cu}>\mathrm{Cd}$. The uptake of $\mathrm{Cd}$ in roots is via a system involved in the transport of another essential divalent micronutrient possibly $\mathrm{Zn}^{2+}$. Cadmium is a chemical analogue of $\mathrm{Zn}$ and plants may not be able to differentiate between the two ions [18]. The bioaccumulation factor (BF) and the transfer factor (TF) for the heavy metal build-up in the plant tissues (Figure 1(b)) indicted that the BF and TF for $\mathrm{Cd}(2.33,1.16), \mathrm{Pb}(1.32,1.93)$, and $\mathrm{Mn}(1.04,2.00)$, respectively, were found to be greater than 1 . The $\mathrm{BF}$ for $\mathrm{Cu}$ (0.42) and $\mathrm{Fe}(0.08)$ were found to be less than 1, but the TF 1.98 for $\mathrm{Cu}$ and 1.61 for $\mathrm{Fe}$, respectively, were greater than 1. The BF and TF of $\mathrm{Zn}$ were both less than $1(0.62,0.96)$. This indicates that the plant roots are able to solubilize and take up the metals from very low levels in the soil, even from nearly insoluble precipitates. The TF is an essential indicator that allows the assessment of mobility of heavy metals in plants [19]. This result implicates Solanum melongena plant as a bioaccumulator of $\mathrm{Fe}, \mathrm{Zn}$, and $\mathrm{Pb}$ and indicates that it can function as hyperaccumulator for $\mathrm{Cd}, \mathrm{Cu}, \mathrm{Fe}, \mathrm{Pb}$, and $\mathrm{Mn}$ [20]. These findings agreed with study carried out by Mukut and Arundhuti [21], Stefan and Todor [22], and Bulent and Kubilay [23].

In Rumex acetosa plant, from the experimental site (Figure 2(a)), it was observed that the concentrations of $\mathrm{Cu}(35.65 \mathrm{mg} / \mathrm{kg}), \mathrm{Fe}(2008 \mathrm{mg} / \mathrm{kg}), \mathrm{Mn}(52.90 \mathrm{mg} / \mathrm{kg})$, and $\mathrm{Zn}(120.83 \mathrm{mg} / \mathrm{kg})$ were higher in the shoot than in the experimental root $(28.90 \mathrm{mg} / \mathrm{kg}, 1916.50 \mathrm{mg} / \mathrm{kg}, 33.60 \mathrm{mg} / \mathrm{kg}$, and $59.95 \mathrm{mg} / \mathrm{kg}$, resp.). The metals were translocated from the root to the above plant tissue $[24,25]$. In Figure 2(b), the $\mathrm{BF}$ and $\mathrm{TF}$ for only $\mathrm{Mn}(1.41,1.57)$ and $\mathrm{Zn}(2.02,1.15)$, respectively, were greater than 1 , which indicates that Rumex acetosa plant can function as hyperaccumulator for $\mathrm{Zn}$ and $\mathrm{Mn}$. 


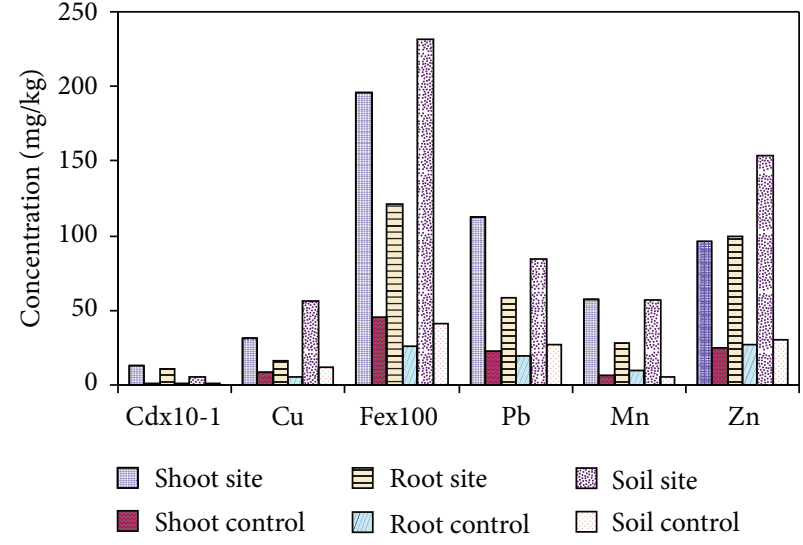

(a)

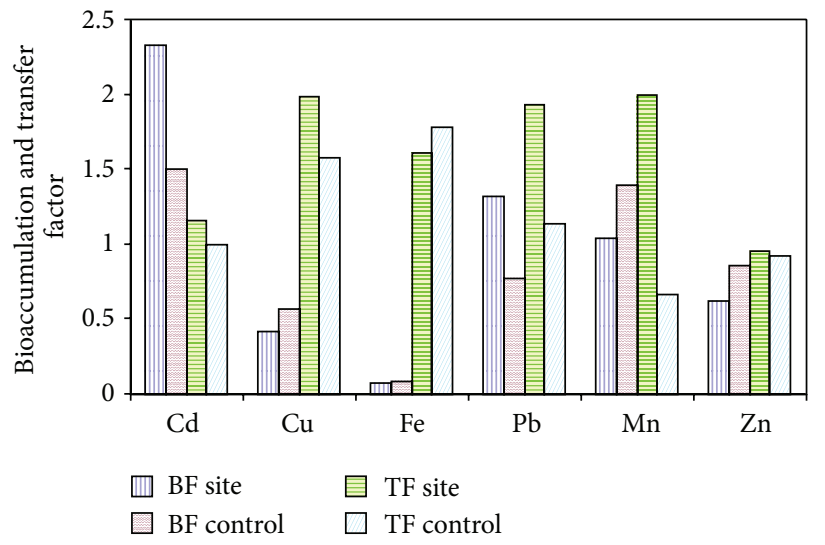

(b)

FIgURE 1: (a) Concentration of metals in Solanum melongena and the soil. (b) Bioaccumulation and transfer factors for Solanum melongena. BF: bioaccumulation factor; TF: transfer factor.

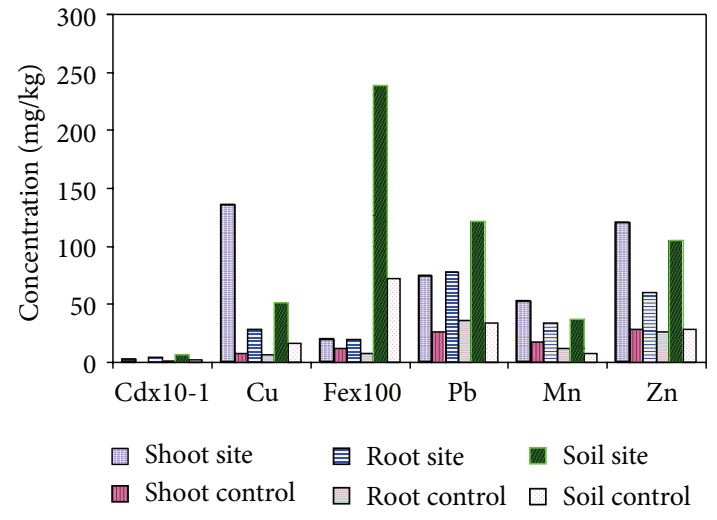

(a)

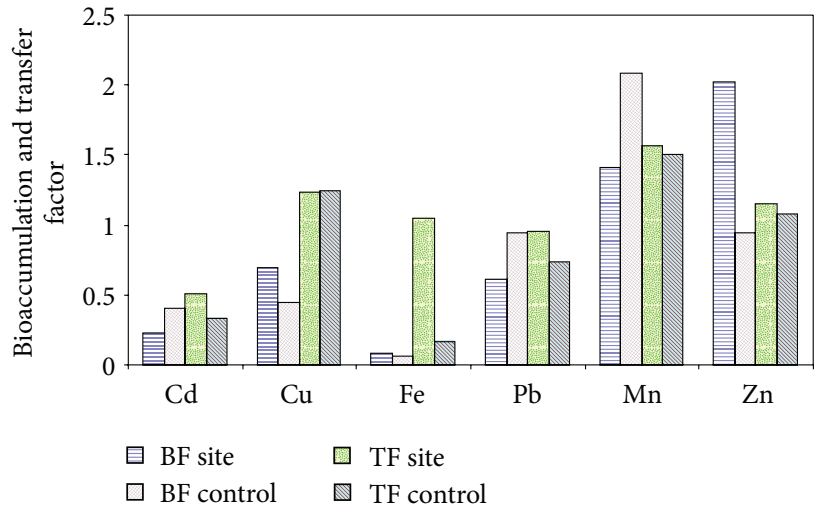

(b)

FIgURE 2: (a) Concentration of metals in Rumex acetosa plant and the soil. (b) Bioaccumulation and transfer factors for Rumex acetosa plant. BF: bioaccumulation factor; TF: transfer factor.

For Lycopersicon esculentum the concentrations of $\mathrm{Cd}$ $(0.28 \mu \mathrm{g} / \mathrm{g})$ and $\mathrm{Cu}(66.00 \mu \mathrm{g} / \mathrm{g})$ in the experimental shoot were lower than those in their root $(0.30 \mu \mathrm{g} / \mathrm{g}$ and $68.95 \mu \mathrm{g} / \mathrm{g}$, resp.), but those of $\mathrm{Pb}(82.38 \mu \mathrm{g} / \mathrm{g})$, Fe $(1474.50 \mu \mathrm{g} / \mathrm{g}), \mathrm{Mn}$ $(19.38 \mu \mathrm{g} / \mathrm{g})$, and $\mathrm{Zn}(175.90 \mu \mathrm{g} / \mathrm{g})$ were higher than in the root $(62.30 \mu \mathrm{g} / \mathrm{g}, 502.50 \mu \mathrm{g} / \mathrm{g}, 18.15 \mu \mathrm{g} / \mathrm{g}$, and $117.80 \mu \mathrm{g} / \mathrm{g}$, resp.). The $\mathrm{BF}$ for all the metals studied were less than 1 , which implies that Lycopersicon esculentum plant is not a bioaccumulator of $\mathrm{Cd}, \mathrm{Cu}, \mathrm{Fe}, \mathrm{Pb}, \mathrm{Mn}$, and $\mathrm{Zn}$ [21].

It was observed that the $\mathrm{BF}$ and $\mathrm{TF}$ for $\mathrm{Cd}$ in Rumex acetosa plant were 0.23 and 0.51 as depicted in Figure 2(b) and for Lycopersicon esculentum plant the values were 0.56 and 0.93 as shown in Figure 3(b) and were all less than 1. This means that these plants are not good bioaccumulators of Cd.

The levels of these heavy metals in the plant and soil samples were generally higher than those of the control counterparts and also above the limits set by the Joint Food and Agricultural Organisation and World Health Organization [26]. The recommended limits are as follows: $\mathrm{Cd}-$ $0.1 \mathrm{mg} / \mathrm{kg} ; \mathrm{Cu}-10 \mathrm{mg} / \mathrm{kg} ; \mathrm{Fe}-0.3 \mathrm{mg} / \mathrm{kg} ; \mathrm{Pb}-0.05 \mathrm{mg} / \mathrm{kg}$; $\mathrm{Mn}-0.3 \mathrm{mg} / \mathrm{kg}$; and $\mathrm{Zn}-5-15 \mathrm{mg} / \mathrm{kg}$. The coefficient of correlation $(r)$ values between the metal levels in soil and plant from Pearson's correlation coefficient is presented in Table 1. A strong positive correlation for all the metals studied, $\mathrm{Cd}(r=0.792), \mathrm{Cu}(r=0.965), \mathrm{Fe}(r=0.932), \mathrm{Pb}(r=$ $823), \mathrm{Mn}(r=0.875)$, and $\mathrm{Zn}(r=0.985)$, was observed. This indicated that this metal level in the soil is the major factor governing the heavy metal contents in the plants studied.

\section{Conclusion}

The soils and plants near the scrap metal dumpsite were found to be enriched with $\mathrm{Cd}, \mathrm{Cu}, \mathrm{Fe}, \mathrm{Pb}, \mathrm{Mn}$, and $\mathrm{Zn}$. So, the planting on the land close to the metal-scrap dumpsite at Gaskiya, Zaria, should be discouraged. The environmental agency should enforce the law prohibiting the use of metalscrap dumpsites for farming activities. Solanum melongena showed $\mathrm{BF}$ and TF greater than 1 for $\mathrm{Cd}(2.33,1.16), \mathrm{Cu}(1.61$, $1.98), \mathrm{Pb}(1.32,1.93)$, and $\mathrm{Mn}(1.04,2.0)$; Rumex acetosa on the other hand had BF and TF greater than 1 for Mn $(1.41,1.57)$ and $\mathrm{Zn}(2.02,1.15)$, and TF was greater than 1 for $\mathrm{Cu}(1.23)$ and 


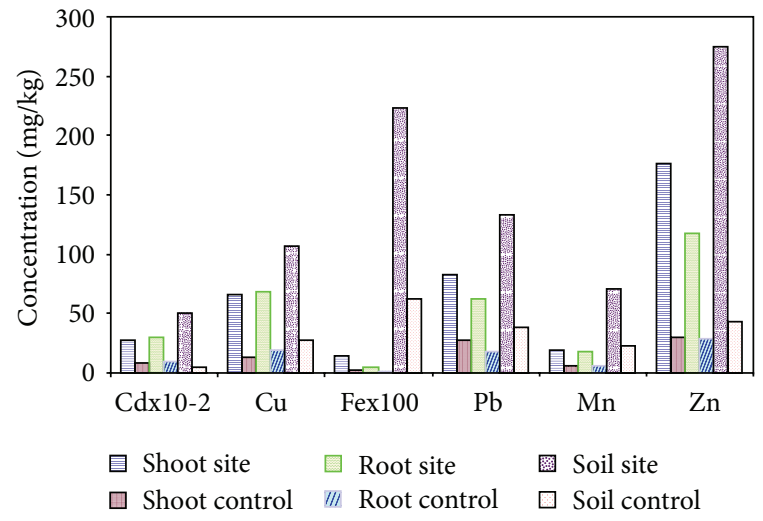

(a)

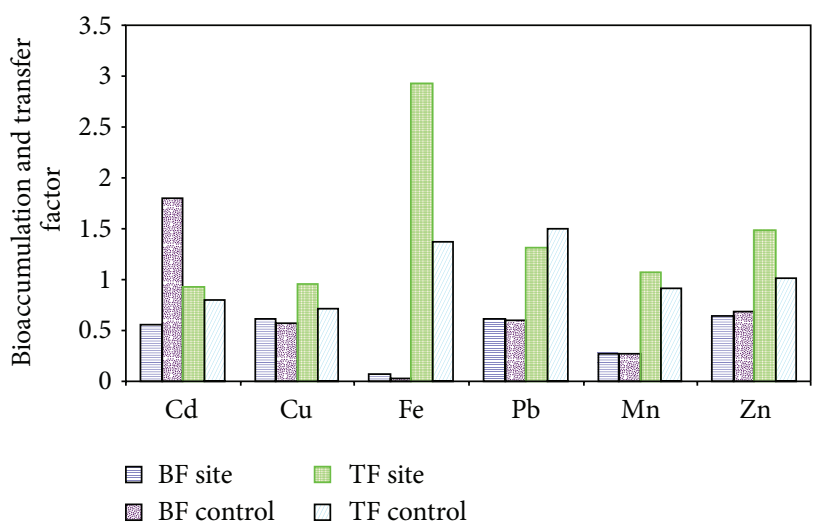

(b)

FIGURE 3: (a) Concentration of metals in Lycopersicon esculentum plant and the soil. (b) Bioaccumulation and transfer factors for Lycopersicon esculentum plant. BF: bioaccumulation factor; TF: transfer factor.

TABle 1: Pearson's correlation coefficient $(r)$ values for metal level between soil and plant.

\begin{tabular}{lcccccc}
\hline & \multicolumn{6}{c}{ Correlation coefficient } \\
& $\mathrm{Cd}$ & $\mathrm{Cu}$ & $\mathrm{Fe}$ & $\mathrm{Pb}$ & $\mathrm{Mn}$ & $\mathrm{Zn}$ \\
\hline Soil and plant & -0.220 & 0.965 & 0.332 & 0.823 & -0.375 & 0.985 \\
\hline
\end{tabular}

Fe (1.05); Lycopersicon esculentum plant had only the TF for Fe (2.93), $\mathrm{Pb}$ (1.32), $\mathrm{Mn}$ (1.07), and $\mathrm{Zn}$ (1.47) being greater than 1 . Therefore, Solanum melongena and Rumex acetosa plants can be used as hyperaccumulators for phytoremediation of $\mathrm{Cd}$, $\mathrm{Cu}, \mathrm{Pb}, \mathrm{Mn}$, and $\mathrm{Zn}$.

\section{Conflict of Interests}

The authors declare that there is no conflict of interests regarding the publication of this paper.

\section{References}

[1] P. C. Nagajyoti, K. D. Lee, and T. V. M. Sreekanth, "Heavy metals, occurrence and toxicity for plants: a review," Environmental Chemistry Letters, vol. 8, no. 3, pp. 199-216, 2010.

[2] V. O. Ajibola and I. I. Funtua, "Status of lead and sulphate contamination in soil around some battery-charging areas of Zaria," Journal of Science, Engineering and Technology, vol. 8, no. 2, pp. 3108-3117, 2001.

[3] E. Pehlivan, A. M. Özkan, S. Dinç, and Ş. Parlayici, "Adsorption of $\mathrm{Cu}^{2+}$ and $\mathrm{Pb}^{2+}$ ion on dolomite powder," Journal of Hazardous Materials, vol. 167, no. 1-3, pp. 1044-1049, 2009.

[4] S. T. Wang and H. P. Demshar, "Determination of blood lead in dried blood-spot specimens by zeeman-effect background corrected atomic absorption spectrometry," Analyst, vol. 117, no. 6, pp. 959-961, 1992.

[5] M. Inuwa, F. W. Abdulrahman, U. A. Birnin Yauri, and S. A. Ibrahim, "Analytical assessment of some trace metals in soils around the major industrial areas of Northwestern Nigeria," Trends in Applied Sciences Research, vol. 2, pp. 515-521, 2007.
[6] R. L. Chaney, M. Malik, Y. M. Li et al., "Phytoremediation of soil metals," Current Opinion in Biotechnology, vol. 8, no. 3, pp. 279-284, 1997.

[7] J. W. Huang, J. Chen, W. R. Berti, and S. D. Cunningham, "Phytoremediadon of lead-contaminated soils: role of synthetic chelates in lead phytoextraction," Environmental Science and Technology, vol. 31, no. 3, pp. 800-805, 1997.

[8] D. E. Salt, R. D. Smith, and I. Raskin, "Phytoremediation," Annual Review of Plant Biology, vol. 49, pp. 643-668, 1998.

[9] R. D. Raskin and A. J. M. Baker, "Metal-accumulating plants," in Phytoremediation of Toxic Metals: Using Plants to Clean Up the Environment, L. Raskin and B. D. Raskin, Eds., pp. 193-229, John Wiley \& Sons, New York, NY, USA, 1999.

[10] W. H. O. Ernst, "Evolution of metal hyperaccumulation and phytoremediation hype," New Phytologist, vol. 146, no. 3, pp. 357-358, 2000.

[11] B. Kos, H. Greman, and D. Lestan, "Phytoextraction of lead, zinc and cadmium from soil by selected plants," Plant, Soil and Environment, vol. 49, no. 12, pp. 548-553, 2003.

[12] A. Smical, V. Hotea, V. Oros, J. Juhasz, and E. Pop, "Studies on transfer and bioaccumulation of heavy metals from soil into lettuce," Environmental Engineering and Management Journal, vol. 7, no. 5, pp. 609-615, 2008.

[13] M. M. Lasat, "Phytoextraction of metals from contaminated soils: a review of plant/soil/metal interaction and assessment of pertinent and agronomic issues," Journal of Hazardous Substance Research, vol. 2, no. 5, pp. 1-25, 2000.

[14] K. Suruchi and K. Pankaj, "Assessment of heavy metal contamination in different vegetables grown in and around urban areas," Research Journal of Environmental Toxicology, vol. 5, no. 3, pp. 162-172, 2011.

[15] L. Nuonom, M. Yemefack, M. Techienkwa, and R. Njongang, "Impact of natural fallow duration on Cameron," Nigerian Journal of Soil Research, vol. 3, pp. 52-57, 2000.

[16] G. C. Kisku, S. C. Barman, and S. K. Bhargava, "Contamination of soil and plants with potentially toxic elements irrigated with mixed industrial effluent and its impact on the environment," Water, Air, \& Soil Pollution, vol. 120, no. 1-2, pp. 121-137, 2000. 
[17] Y. Sun, Q. Zhou, Y. Xu, L. Wang, and X. Liang, "The role of EDTA on Cadmium phytoextraction in a Cadmium-hyperaccumulator Rorippa globosa," Journal of Environmental Chemistry and Ecotoxicology, vol. 3, no. 3, pp. 45-51, 2011.

[18] R. L. Chaney, C. E. Green, E. Filcheva, and S. L. Brown, "Effect of iron, manganese, and zinc-enriched biosolids compost on uptake of cadmium by lettuce from cadmium-contaminated soils," in Sewage Sludge: Land Utilization and the Environment, C. E. Clap, W. E. Larson, and R. H. Dowdy, Eds., pp. 205-207, American Society of Agronomy, Madison, Wis, USA, 1994.

[19] F. J. Zhao, R. E. Hamon, and M. J. McLaughlin, "Root exudates of the hyperaccumulator Thlaspi caerulescens do not enhance metal mobilization," New Phytologist, vol. 151, no. 3, pp. 613-620, 2001.

[20] M. N. V. Prasad, "Phytoremediation of metal-polluted ecosystems: hype for commercialization," Russian Journal of Plant Physiology, vol. 50, no. 5, pp. 686-700, 2003.

[21] K. Mukut and D. Arundhuti, "Uptake of metals by four commonly available plants species collected from crude oil contaminated sites at Lakowa oil field," International Journal of Agricultural Science and Research, vol. 2, no. 4, pp. 121-134, 2012.

[22] S. Stefan and B. Todor, "Heavy metal accumulation in Solanaceae-plants grown at contaminated area," in Proceedings of the Balkan Scientific Conference of Biology, pp. 452-460, Povdiv, Bulgaria, 2005.

[23] T. Bulent and M. O. Kubilay, Heavy Metals Accumulation in the Eggplant (Solanum melongena), Environmental Pollution and Control Department, Antalya, Turkey, 2007.

[24] R. B. Corey, R. Fujii, and L. L. Hendickson, "Bioavailability of heavy metal in soil-sluge systems," in Proceedings of the 4th Annual Madison Conference, University of Wisconsin, 1981.

[25] S. A. Barber, Soil Nutrient Bioavailability, John Wiley \& Sons, New York, NY, USA, 1984.

[26] FAO/WHO, Evaluation of Certain Food Additives and Contaminants, vol. 859, Technical Report Series, 1995. 

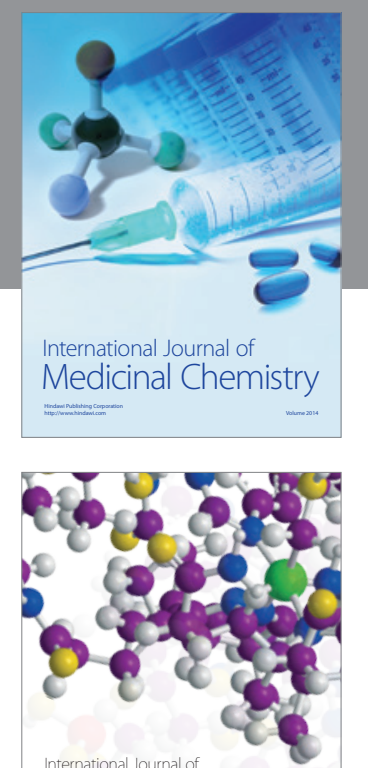

\section{Carbohydrate} Chemistry

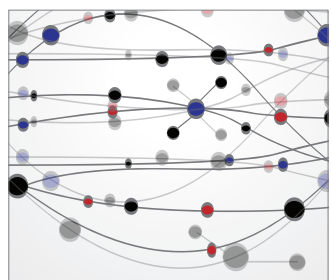

The Scientific World Journal
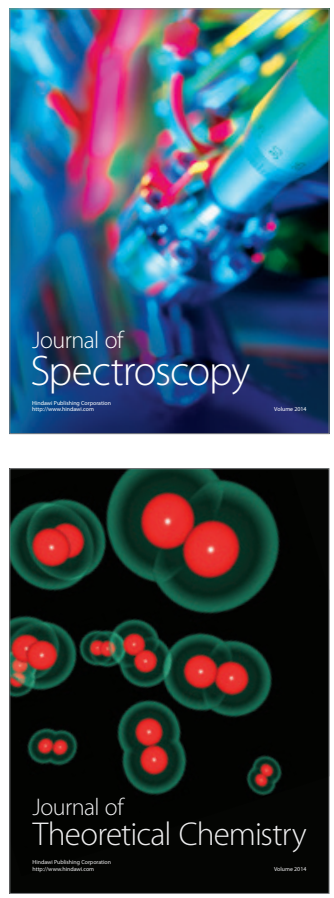
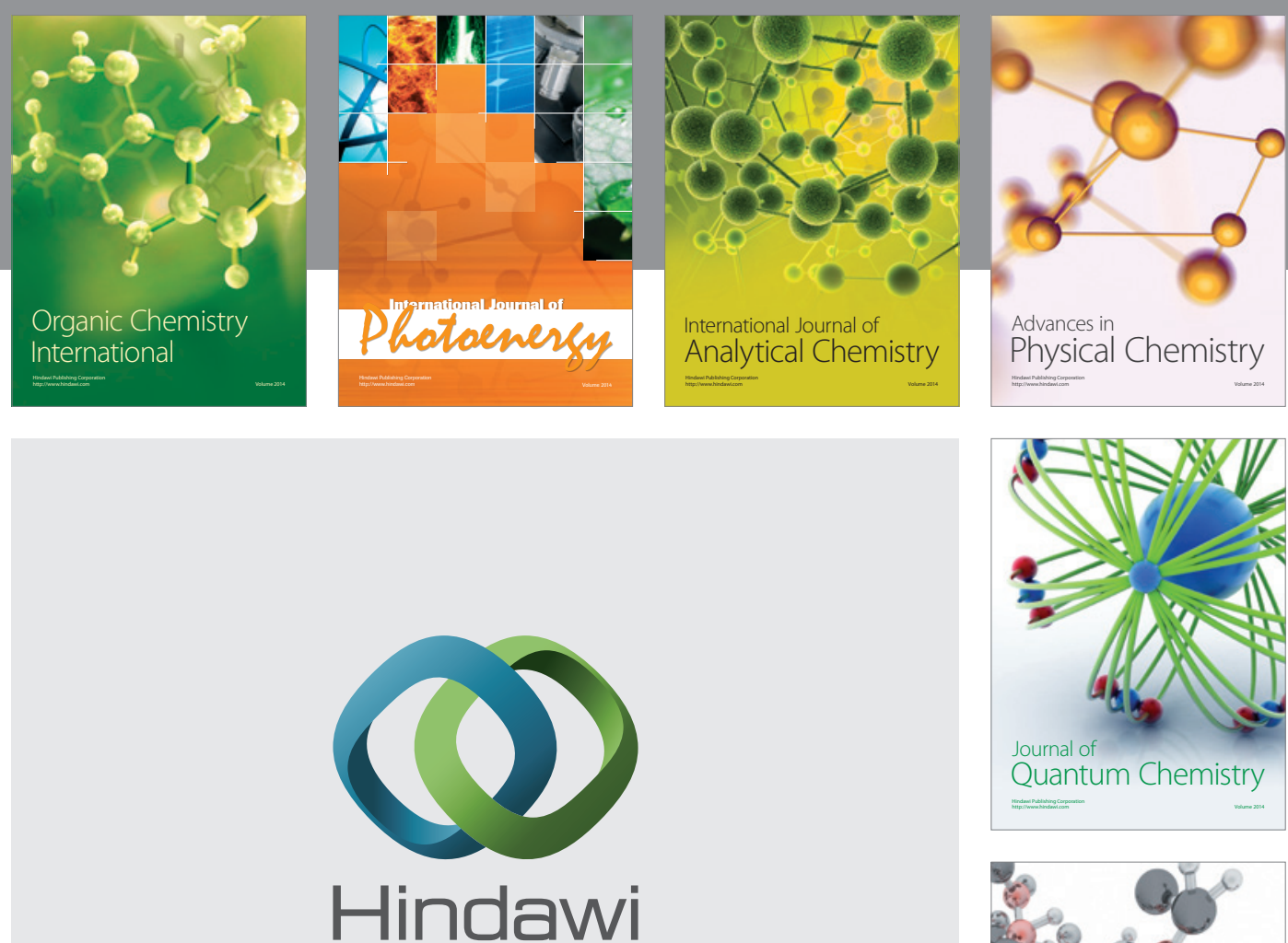

Submit your manuscripts at

http://www.hindawi.com

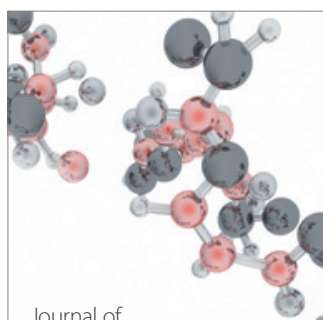

Analytical Methods

in Chemistry

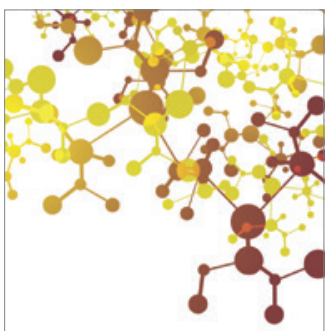

Journal of

Applied Chemistry

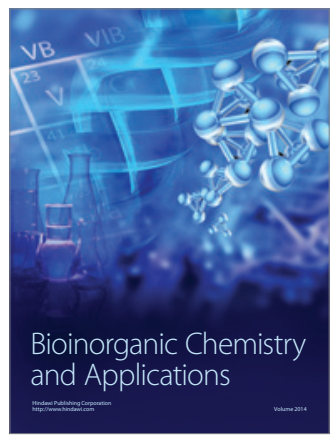

Inorganic Chemistry
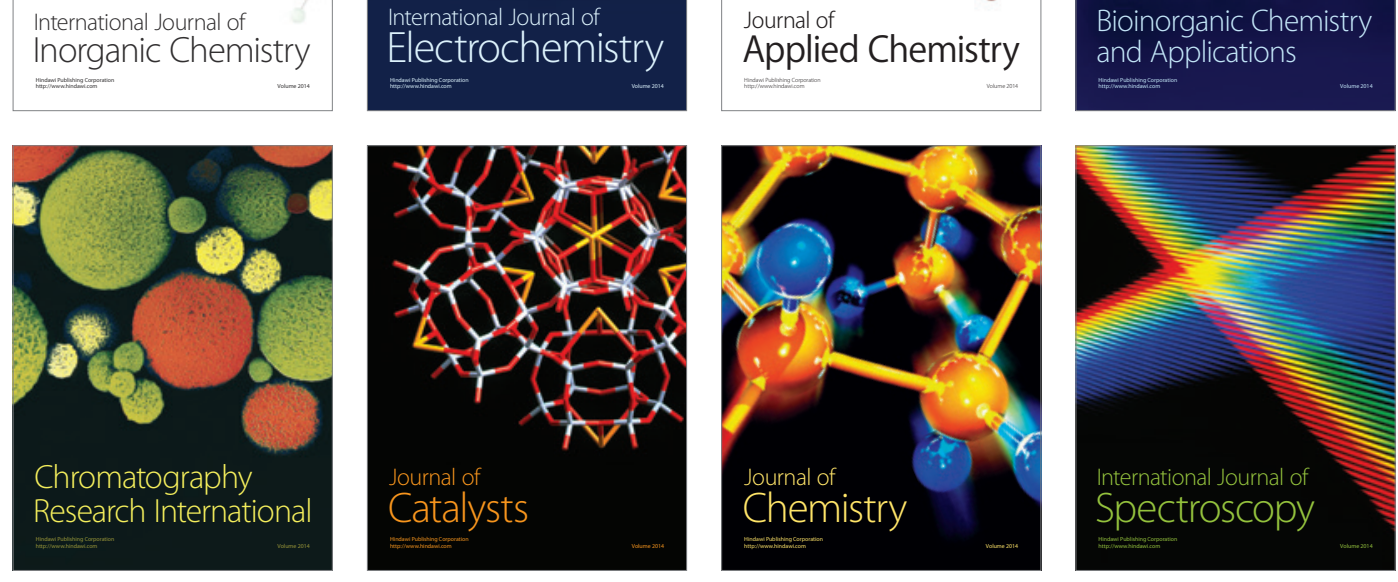